\title{
Paraplegia due to missed thoracic meningioma after lumbar spinal decompression surgery: A case report and review of the literature
}

\author{
Lomber spinal dekompresyon cerrahisi sonrası gözden kaçan torakal meningioma nedeniyle \\ gelişen parapleji: Olgu sunumu ve literatür taraması
}

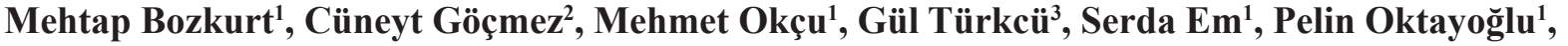 \\ Demet Uçar ${ }^{1}$, Kemal Nas ${ }^{1}$
}

\begin{abstract}
Spinal meningiomas are often localized to the thoracic level and symptoms from a spinal meningioma are determined by the location of the mass. We present a case of thoracic paraplegia due to a thoracic spinal cord tumor (meningioma) that was not detected during lumbar spinal decompressive surgery. Thoracic mass was detected in level of T2-3 on magnetic resonance imaging (MRI). The patient was re-operated and the patient's neurologic symptoms were partially relieved. Surgeons should know that a thoracic silent meningioma can aggrevate neurological symptoms after lumbar spinal decompression surgery and should inform their patient before surgery.
\end{abstract}

Key words: Lumbar surgery, meningioma, thoracic paraplegia

\section{INTRODUCTION}

Meningiomas are among the most frequent primary brain tumors [1]. Meningiomas are generally slow growing and discovered incidentally at neuroimaging studies. Approximately $10 \%$ of meningiomas arise from spine. Meningiomas comprise of about $25 \%$ of spinal cord tumors and more often seen in females $[2,3]$. They are localized to the thoracic level and intradural extramedullary space of the spinal cord $[3,4]$. Symptoms can vary widely depending on by the location of the mass. Generally, these are asymptomatic or minimally symptomatic. Spinal meningiomas frequently present with progressive leg weakness and numbness. Lumbar disc herniation or spinal stenosis [5] may mimic symptoms

\section{ÖZET}

Spinal meningiomlar genellikle torakal seviyede localize olurlar ve kliniği kitlenin bulunduğu yere göre değişir. Çalışmamızda lomber spinal dekopresyon cerrahisi sırasında tespit edilmeyen ve paraplejiye sebep olan torakal spinal kord tümörü (meningioma) vakasını sunuyoruz. Hastada manyetik rezonans görüntüleme ile T2-3 düzeyinde torakal kitle saptandı. Hasta yeniden ameliyat edildi ve hastanın nörolojik semptomlar kısmen düzeldi. Cerrahlar, semptomsuz bir torakal menenjiomanın lomber spinal dekompresyon cerrahisi sonrası hastanın nörolojik semptomlarını şiddetlendirebileceğini bilmeleri ve ameliyat öncesi hastalarını bilgilendirmeleri gerekmektedir.

Anahtar kelimeler: Lomber cerrahi, meningioma, torasik parapleji

of meningioma. Careful physical examination and MRI can reveal this situation before spinal decompressive surgery.

In this report, we describe one case of lowerextremity motor weakness due to a thoracic spinal cord tumor (meningioma) that was not detected during lumbar spinal decompressive surgery. To our knowledge, this is the fourth report of cases in the literature and additionally we highlight details in other cases.

\section{CASE REPORT}

A 55-year-old male patient was admitted to our rehabilitation clinic with complaints of paraplegia (lower-extremity motor weakness), urinary inconti-

\footnotetext{
${ }^{1}$ Department of Physical Medicine and Rehabilitation, School of Medicine, Dicle University, Diyarbakir, Turkey

${ }^{2}$ Department of Neurosurgery, School of Medicine, Dicle University, Diyarbakir, Turkey

${ }^{3}$ Department of Pathology, School of Medicine, Dicle University, Diyarbakır, Turkey

Yazışma Adresi /Correspondence: Mehtap Bozkurt,

Department of Physical Medicine and Rehabilitation, University of Dicle, Diyarbakır, Turkey Email: drmehtapbozkurt@hotmail.com

Geliş Tarihi / Received: 21.10.2013, Kabul Tarihi / Accepted: 30.12.2013

Copyright @ Dicle Tıp Dergisi 2014, Her hakkı saklıdır / All rights reserved
} 
nence and fecal incontinence. About 9 months ago; decompressive surgery was performed at L4 level for low-back pain, right leg pain and bilateral neurogenic claudication by a neurosurgery in another hospital. The patient's symptoms decreased in the early postoperative period, but they got worse in a week after surgery. Four months later, a second operation was performed at the levels of L3-L4-L5-S1 and posterior segmental instrumentation by another neurosurgery at out of our hospital. The patient reports no change after the second surgery.

Hypoesthesia and deficit in deep sensory perception at the T4 level were present on physical examination. The reflex of patella tendon and the reflex of Achilles tendon were hypotonic. Lowerextremity motor weakness: right iliopsoas, quadriceps and hamstrings were grade 0 , left iliopsoas, quadriceps, hamstrings were grade 1 and right and left tibialis anterior were grade 0 and 4 , respectively. In addition, a significant spasticity (Ashworth 3) was present in both lower extremities and Babinski reflexes were bilaterally positive.

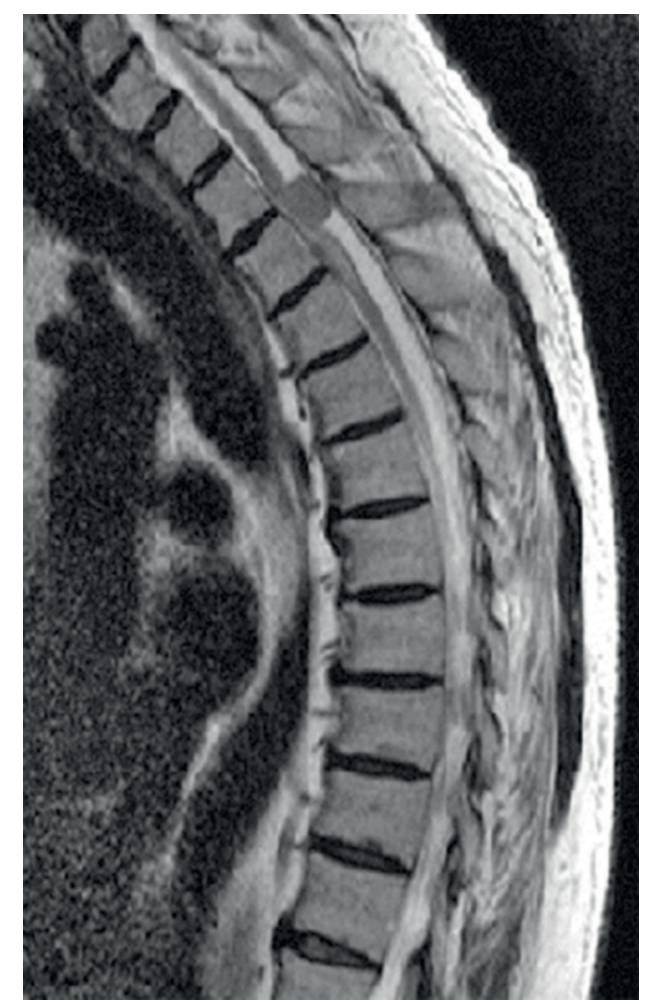

Figure 1. Magnetic resonance imaging findings of thoracic spine extramedullary intradural mass; suspicious meningioma at T2-3 level.

On MRI; there was posterior spinal cord compression at the T2-T3 levels. On T2-weighted imag- es, hyperintense myelomalasic changes were present, which after contrast administration were found to be a properly nodular mass contrast intensely (Figure 1). A third operation was performed to excise the tumor at the T2-3 level, which histopathological examination showed to be a meningomyelomatous meningioma (Figure 2). Postoperatively, the patient's neurologic symptoms were partially relieved.

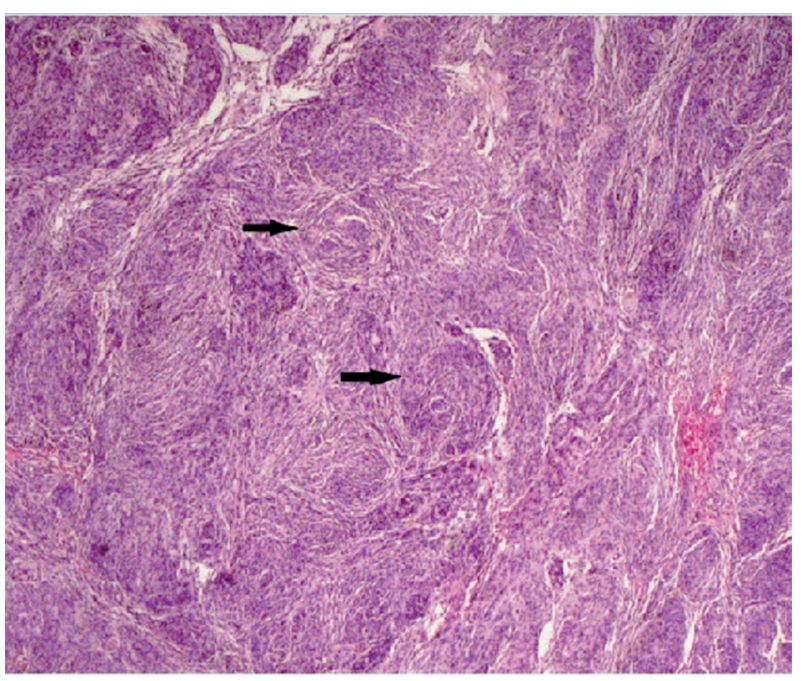

Figure 2. Lobulated and whorled aggregates of polygonal to epithelioid tumor cells, some partly bounded by thin collagenous septa. The lobules of tumor cells indicated by arrows (HE, X25)

\section{DISCUSSION}

It was postulated that disorder in the field of neurological surgery at the level of the above occurs as a result of dynamic changes in the flow of cerebrospinal fluid. But, this has not been proven. Boccanera and Laus [6] demonstrated that the pressure changes resulted from previous decompressive surgery constricted the neural elements and led to neurological deterioration at the level of the previously existing missed compression. Valls et al. [6] demonstrated that dynamic changes in cerebrospinal fluid flow caused by the operation may affect the missed thoracic arachnoid cyst and result in deteriorating of neurologic symptoms. Furthermore, Turker et al [8] reported in two cases that neurological deterioration was due to spinal cord infarction and cord edema. Takeuchi et al [9] discussed in two cases that first lumbar decompressive surgery impacts on the flow dynamics of cerebrospinal fluid leading to the thoracic compressive lesions to become symptomatic. 
Meningioma is aggravated by all these mechanisms and may cause of acute neurological symptoms. However, pathophysiologic mechanism of meningioma is not fully determined.

Spinal meningiomas grow slowly and spread laterally in the subarachnoid space until they induce symptoms [10]. They most frequently occur in the thoracic region in middle-aged women. Patients typically present with pain, sensory loss, weakness, and sphincter disturbances. Prognosis of spinal meningioma is excellent even patients with a poor preoperative neurological status. After lumbar spinal decompression surgery; operative site hematoma, nerve root injury [11] and cauda equina syndrome
[12] have been reported as common complications. However, a deteriorating neurologic symptom has been rarely reported as a result of a coexisting lesion above the level of the operative site. The cause may be due to dynamic changes in cerebrospinal fluid flow $[6,7,9]$. However, the exact pathophysiological mechanism could not be determined. Radiological and surgical auxiliary devices has resulted in advances in early diagnosis and helped to achieve total resection.

To date, only three paraplegias due to missed thoracic meningioma after laminotomy for lumbar spinal stenosis have been described in the literature (Table 1).

Table 1. Paraplegia due to missed thoracic meningioma after laminectomy for lumbar spinal decompression surgery: concepts and review of reported cases

\begin{tabular}{|c|c|c|c|c|c|c|c|}
\hline Author & Age & sex & Location & $\begin{array}{l}\text { Symptoms after } \\
\text { decompression surgery }\end{array}$ & Pathology & Treatment & Outcome \\
\hline $\begin{array}{l}\text { Akihiko } \\
(2004)\end{array}$ & 64 & Female & T5-6 & $\begin{array}{l}\text { Urinary-fecal incontinence, } \\
\text { bilaterally lower extremity } \\
\text { motor weakness. }\end{array}$ & Meningioma & Total resection & $\begin{array}{l}\text { Neurological } \\
\text { status improved }\end{array}$ \\
\hline \multirow[b]{2}{*}{$\begin{array}{l}\text { Sang-Bang } \\
\text { (2011) }\end{array}$} & 73 & Female & T3-4 & $\begin{array}{l}\text { Low-back pain, insidious } \\
\text { onset of bilateral neurogenic } \\
\text { claudication and lower-extremity } \\
\text { motor weakness. }\end{array}$ & Meningioma & Excise the tumor & $\begin{array}{l}\text { Neurological status } \\
\text { improved, including } \\
\text { urinary function, } \\
\text { anal tone, and } \\
\text { motor function }\end{array}$ \\
\hline & 63 & Female & T3-5 & $\begin{array}{l}\text { Low-back pain, bilateral } \\
\text { neurogenic claudication } \\
\text { and lower-extremity } \\
\text { motor weakness. }\end{array}$ & Meningioma & Excise the tumor & $\begin{array}{l}\text { Neurological } \\
\text { status improved }\end{array}$ \\
\hline $\begin{array}{l}\text { This case } \\
\text { (2013) }\end{array}$ & 55 & Male & T2-3 & $\begin{array}{l}\text { Urinary-fecal incontinence } \\
\text { Bilaterally lower extremity } \\
\text { motor weakness. }\end{array}$ & Meningioma & Total resection & $\begin{array}{l}\text { Neurologic symptoms } \\
\text { were partially relieved }\end{array}$ \\
\hline
\end{tabular}

Sang-Bang Ko et al. [13] reported two cases. In the first case, a decompressive surgery was performed at L4-5-S1. Two weeks after the operation, an intradural extramedullary tumor was detected. In the second case, a decompressive surgery was performed at L3-4-5. On the 3rd postoperative day, the patient displayed lower-extremity motor weakness bilaterally. Seven days after the 1st operation, a second operation was performed to excise the tumor. Akıhıko Takeuchı et al [9] reported a case in which a decompressive surgery was performed at L2 -5 . Although, the early postoperative period was uneventful, on the 6th postoperative day the patient displayed lower-extremity motor weakness bilaterally. Our patient underwent a decompressive surgery which was performed at L4 and four months later, a second operation was performed at the levels of L3-L4-L5-S1 and posterior segmental instrumentation. Hypoesthesia and deficit in deep sensory perception were seen on physical examination at the above level of surgery. Thoracic mass was detected in level of T2-3 on MRI and the tumour was more common in the upper thoracic level (Figure 1). Like other cases, our patient was operated and postoperatively the patient's neurologic symptoms were partially relieved. Other cases described onset of dysesthesia, motor deficits, and urinary retention after surgery for spinal decompression surgery. Our patient suffered from simultaneous sensory, motor deficits and incontinence. Generally, meningiomas are more common in women, with a female to male 
ratio of about two or three to one [14]. All of other cases were women but our case was men.

In conclusion, meningiomas may demonstrate a clinical presentation similar to lumbar disc hernias and spinal stenosis. Thoracic paraplegia occurred in all four cases because compressive thoracic lesions were not detected during initial lumbar decompressive surgery.

To avoid such a complication, we suggest that carefull examination of the thoracic spine including sensory and motor function tests should be performed preoperatively if lumbar imaging is inconclusive or incompatible with the history and physical examination.

\section{REFERENCES}

1. Whittle IR, Smith C, Navoo P, et al. Meningiomas. Lancet 2004;363:1535-1543.

2. Tomura N. imaging of tumors of the spine and spinal cord]. Nihon Igaku Hoshasen Gakkai Zasshi 2000; 60:302-311.

3. Covert S, Gandhi D, Goyal M, et al. Magnetic resonance imaging of intramedullary meningioma of the spinal cord: Case report and review of the literature. Can Assoc Radiol J 2003;54:177-180.

4. Salvati M, Artico M, Lunardi P, et al. Intramedullary meningioma: Case report and review of the literature. Surg Neurol 1992;37:42-45.
5. Yakut F, Özlu MM,Taşdemir N. Magnetic resonance imaging findings of redundant nerve roots syndrome. Dicle Med J 2012;39: 213-216.

6. Boccanera L, Laus M. Cauda equina syndrome following lumbar spinal stenosis surgery. Spine 1987;12:712-715.

7. Valls PL, Naul LG, Kanter SL. Paraplegia after a routine lumbar laminectomy: Report of a rare complication and successful man-agement. Neurosurgery 1990;27:638-640.

8. Turker RJ, Slack C, Regan Q. Thoracic paraplegia after lumbar spinal surgery. J Spinal Disord 1995;8:195-200.

9. Takeuchi A, Miyamoto K, Hosoe H, et al. Thoracic paraplegia due to missed thoracic compressive lesions after lumbar spinal de-compression surgery. Report of three cases. J Neurosurg 2004;100:71-74.

10. Ciappetta P, Domenicucci M, Raco A. Spinal meningiomas: Prognosis and recovery factors in 22 cases with severe motor defi-cits. Acta Neurol Scand 1988;77:27-30.

11. Bertrand G. The "battered" root problem. Orthop Clin North Am 1975;6:305-310.

12. Kostuik JP, Harrington I, Alexander D, et al. Cauda equina syndrome and lumbar disc herniation. J Bone Joint Surg Am 1986;68:386-391.

13. Ko SB, Lee SW, Shim JH. Paraplegia due to missed thoracic meningioma after laminotomy for lumbar spinal stenosis: Report of two cases. Asian Spine J 2011;5:253-257.

14. Marosi C, Hassler M, Roessler K, et al. Meningioma. Crit Rev Oncol Hematol 2008;67:153-171. 